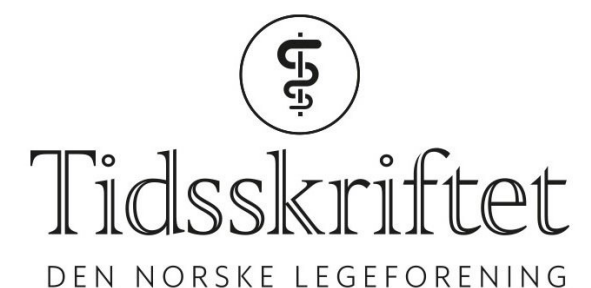

DEN NORSKE LEGEFORENING

\title{
Hvordan beskrive delirium?
}

SPRÅKSPALTEN

\section{BJØRN ERIK NEERLAND}

E-post: bjorn.erik@neerland.net

Bjørn Erik Neerland (f. 1976) er overlege ved Geriatrisk avdeling, Oslo universitetssykehus, og forsker på delirium.

\section{MARIA KROGSETH}

Maria Krogseth (f. 1983) er lege og postdoktorstipendiat ved Geriatrisk avdeling, Oslo universitetssykehus.

\section{TORGEIR BRUUN WYLLER}

Torgeir Bruun Wyller (f. 1960) er spesialist i indremedisin og i geriatri, professor i geriatri ved Universitetet i Oslo og overlege ved Oslo universitetssykehus.

I beskrivelsen av symptomene ved delirium brukes flere engelske ord som ikke er lette å oversette til norsk. Hva skal vi kalle awareness, arousal, alertness, attention og consciousness?

De fleste deliriumforskere benytter kriteriene i diagnosesystemet Diagnostic and Statistic Manual (DSM-5) (1). Det er særlig ett av punktene som er vanskelig å oversette.

Originalversjonen er slik: «A disturbance in attention (i.e., reduced ability to direct, focus, sustain, and shift attention) and awareness (reduced orientation to the environment)».

Forstyrrelse av attention og awareness er tillagt $\varnothing$ kende betydning med nyere versjoner av DSM, og ses nå som de mest sentrale symptomene ved delirium.

\section{Tre nivåer}

Disse begrepenes innhold og innbyrdes sammenheng diskuteres til dels livlig innenfor mange grener av medisin og psykologi (2). Blant deliriumforskere synes det å være enighet om å betrakte funksjonene i en forenklet, hierarkisk modell med tre arbitrære nivåer.

Laveste nivå er fenomener som på engelsk kalles awareness, arousal og alertness. Alt dette har å gjøre med våkenhet eller aktivering og bedømmes typisk ved å vurdere hvor sterkt stimulus som er nødvendig for å fremkalle en normal respons. Bevissthetsskalaen Glasgow Coma Scale (GCS) bygger på et slikt prinsipp. Instrumenter som benyttes ved evaluering av delirium, har en lignende oppbygning, men evalueringen gjøres noe bredere. Eksempler er Observational Scale of Level of Arousal (OSLA) $(3,4)$ og Richmond Agitation Sedation Scale (RASS) (5).

Våkenhet dekker ett aspekt ved begrepet arousal, ettersom dette ordet beskriver et kontinuum som kan omfatte døsig og våken. Men arousal kan også være patologisk økt. Da er pasienten agitert. Den fulle bredden i begrepet arousal dekkes derfor ikke av det norske ordet våkenhet alene. Man må benytte begge begrepene våkenhet og agitasjon. 
Awareness og alertness oppfatter vi som synonymer. Disse begrepene er svært nært beslektet med arousal, men omfatter muligens et mer kvalitativt aspekt ved pasientenes opplevelse av seg selv og omverdenen. Vi foreslår at både aware og alert best oversettes med klar. Dette er et ord det er sterkt tradisjon for å benytte i medisinske journaler, ofte som ledd i frasen «våken, klar og orientert». Den tilsvarende frasen i engelskspråklige pasientjournaler er "awake, alert and oriented», hvilket også passer med at alert oversettes med klar. Hvorvidt pasienten er klar, kan bedømmes ved å ta stilling til om hun eller han oppfører seg normalt i den aktuelle situasjonen, medvirker i samtalen, oppfatter det som skjer i rommet og responderer adekvat.

Midterste nivå i begrepshierarkiet kalles attention på engelsk. På norsk oversettes dette som regel med oppmerksomhet, og omhandler pasientens evne til å holde fast ved en oppgave. Dette kan testes med enkle «baklengstester», f.eks. pasientens evne til å si årets måneder eller ukens dager baklengs. Hvis laveste nivå (våkenhet, agitasjon, klarhet) er unormalt, er det svært sannsynlig at nivå 2 også er det, for man må være våken og klar for å kunne være oppmerksom.

Consciousness brukes i denne tradisjonen som en samlebetegnelse for nivå $1 \operatorname{og} 2$, og her tror vi bevissthet er godt innarbeidet som norsk oversettelse.

Toppnivået i modellen er lett å oversette. Cognition på engelsk heter kognisjon på norsk, og omfatter elementer som hukommelse, orientering, språk, visuospatiale og eksekutive evner. Hvis nivå 1 og/eller 2 er unormale, vil det også påvirke nivå 3 slik at prestasjonen på kognitive tester er dårlig. Demens rammer typisk primært nivå 3, og først i langt fremskredne tilfeller nivå 2 og 1 . Med delirium er det omvendt, denne tilstanden rammer nivå 1 og 2, og som en konsekvens av det blir nivå 3 også påvirket.

\section{Konklusjon}

Blant leger er det tradisjon for å vurdere aspekter ved kognisjon hos pasientene, f.eks. hukommelse og orientering. Skal man stille diagnosen delirium, må man også bedømme grad av våkenhet, agitasjon, klarhet og oppmerksomhet. Da er det en fordel å ha orden i begrepene ( $\operatorname{tab} 1)$.

\section{Tabell 1}

Fem nøkkelbegreper i beskrivelsen av delirium med forslag til norsk oversettelse

\begin{tabular}{|ll|}
\hline Engelsk begrep & Forslag til norsk oversettelse \\
\hline Arousal & Døsighet - våkenhet - agitasjon \\
\hline Alertness & Klarhet \\
\hline Awareness & \\
\hline Attention & Oppmerksomhet \\
\hline Consciousness & Bevissthet \\
\hline
\end{tabular}

\section{LITTERATUR:}

1. American Psychiatric Association. DSM-5 Classification. Washington, DC: American Psychiatric Publishing, 2013.

2. Marchetti G. Against the view that consciousness and attention are fully dissociable. Front Psychol 2012;3:36. [PubMed][CrossRef]

3. Tieges Z, McGrath A, Hall RJ et al. Abnormal level of arousal as a predictor of delirium and inattention: an exploratory study. Am J Geriatr Psychiatry 2013; 21: 1244 - 53. [PubMed][CrossRef]

4. Observasjonsskala for bevissthetsnivå.

http://legeforeningen.no/Fagmed/Norsk-geriatrisk-forening/Geriatrisk-test-og-undervisningsmaterie 
1l/tester-og-registreringsskjemaer/Observasjonsskala-for-bevissthetsniva-OSLA (20.1.2018).

5. Ely EW, Truman B, Shintani A et al. Monitoring sedation status over time in ICU patients: reliability and validity of the Richmond Agitation-Sedation Scale (RASS). JAMA 2003; 289: 2983 - 91.

[PubMed][CrossRef]

Publisert: 5. mars 2018. Tidsskr Nor Legeforen. DOI:10.4045/tidsskr.18.0087

(C) Tidsskrift for Den norske legeforening 2020. Lastet ned fra tidsskriftet.no 